\title{
Albright hereditary osteodystrophy: dental management case report
}

\author{
Osteodistrofia hereditária de albright: relato de caso de manejo odontológico
}

Stephanie Anagnostopoulos FRIEDRICH ${ }^{1}$

Jonas RODRIGUES'

Berenice Barbachan e SILVA'

\section{ABSTRACT}

Albright hereditary osteodystrophy is a disorder comprising phenotypic characteristics of genetic origin, such as short stature, obesity, and brachydactyly. It is a rare disorder and is related to pseudohypoparathyroidism. Within dentistry, it may be associated with enamel hypoplasia and late eruption. Furthermore, due to neurological problems, these patients may impose behavioural difficulties during dental appointments. The present study aims to describe the case of a patient with a possible diagnosis of Albright hereditary osteodystrophy, presenting symptoms and limitations to dental management.

Indexing terms: Dental care. Oral manifestations. Pseudohypoparathyroidism.

\section{RESUMO}

A Osteodistrofia Hereditária de Albrighth é uma alteração que compreende características fenotípicas de origem genética, tais como baixa estatura, obesidade e braquidactília. É uma desordem rara e está relacionada com o pseudo-hipoparatireoidismo. No âmbito da Odontologia pode estar associada à hipoplasia de esmalte e erupção tardia dos dentes. Além disto em função de problemas neurológicos estes pacientes podem impor dificuldades de comportamento no momento do atendimento. O presente estudo objetivou descrever um caso clínico de uma paciente, com o possível diagnóstico de Osteodistrofia Hereditária de Albright, apresentando sintomas e limitações ao tratamento odontológico.

Termos de indexação: Assistência odontológica. Manifestações bucais. Pseudo-hipoparatireoidismo.

\section{INTRODUCTION}

Fuller Albright first described Albright hereditary osteodystrophy (AHO) in 1942, and it is characterised by a set of physical changes that are mainly identified in patients with the rare metabolic disorder of autosomal dominant aetiology, related to pseudohypoparathyroidism (PHP). The term PHP is associated with patients with characteristics of endocrine disorder, such as hypocalcaemia, hypophosphatemia, and resistance to parathyroid hormone (PTH). It is classified by some authors as PHP-1a, PHP-1b, PHP-1c, and PHP-2, according to the characteristics and clinical aspects ${ }^{1-2}$. In addition, pseudo-pseudohypoparathyroidism (PPHP) is the name used to describe patients with the Albright phenotype but without the laboratory findings ${ }^{1-2}$. The PHP-1a type is the most common of them, being characteristic of AHO patients. In most cases, PHP-1b is inherited from the mother, while PPHP is inherited from the father ${ }^{1-5}$. The presence of $\mathrm{AHO}$ and resistance to several hormones with normal Gs are characteristic of individuals with PHP $1 c^{1,2,5}$. Moreover, PHP-2 can be an acquired condition, since its defect has not yet been identified and may not be related to genetic inheritance ${ }^{1,6}$.

Currently, the term AHO is used only to indicate physical characteristics regardless of biochemical findings. The main characteristics described in the literature are short stature, round face, obesity, brachydactyly (poor formation of the fingers and toes), subcutaneous ossifications8, short neck, hypothyroidism, enamel hypoplasia, and late eruption of the teeth, ${ }^{5,9-12}$ and characteristics may also include intellectual disability, hypocalcaemia, and osteoporosis.

Other dental findings have also been reported, such as dental root shortening, dental crowding, severe gingivitis, severe chronic periodontitis, poor tooth

\footnotetext{
${ }^{1}$ Universidade Federal do Rio Grande do Sul, Faculdade de Odontologia. Rua Ramiro Barcelos, 2492, 90035-003, Porto Alegre, RS, Brasil. Correspondência para / Correspondence to: AS FRIEDRICH. E-mail: <stephanie-friedrich@hotmail.com>

$\mathbf{v} \mathbf{v}$

Como citar este artigo / How to cite this article

Friedrich SA, Rodrigues J, Silva BB. Albright hereditary osteodystrophy: dental management case report. RGO, Rev Gaúch Odontol. 2018;66(1):106110. http://dx.doi.org/10.1590/1981-863720180001000153289
} 
formation, malocclusion, and the presence of several decayed teeth ${ }^{3,10-13}$.

The diagnosis of AHO is based on the clinical condition associated with hypocalcaemia and elevated levels of PTH, whereas the classification of the type of PHP is done through genetic investigation ${ }^{6}$.

The objective of this study is to describe a clinical case of a patient attending the dental service associated with an extension programme of the Faculty of Dentistry of the Federal University of Rio Grande do Sul (UFRGS). Due to the rarity of this type of case, it was necessary to clarify the care and conduct necessary to the integral approach of this type of patient in dental treatment.

\section{CLINICAL CASE}

A white female patient, 7 years old, sought dental treatment in the postgraduate programme for dental care of patients with general chronic diseases. A professional referred the patient and her caregivers from her city to the university to obtain dental treatment. The patient arrived with her mother and grandmother. Due to a likely intellectual dependence on the child's mother, all therapeutic decisions to be made for the child were made by the grandmother, who reported on her dental needs, helping to dissuade the granddaughter who was unwelcoming of dental treatment.

The patient has hypothyroidism, obesity (weight: 49 kg/height: $115 \mathrm{~cm}$ ), asthma, delayed neuropsychomotor development (presenting communication difficulties), and suspected PHP (AHO). It presents characteristics typical of $\mathrm{AHO}$, such as obesity, round face, and the shortening of the neck (Figure 1).

The patient is treated for hypothyroidism with Puran t4, a hormone replacement with levothyroxine; for hypocalcaemia with $\mathrm{CaCO} 300$ mg BID; for asthma control and prevention with Salbutamol; for regular treatment of asthma with Seretide; and for treatment of PHP with Calcitriol.

At the first dental appointment, anamnesis, a dental examination, a periodontal examination with the visible plaque index (VPI) and gingival bleeding index (GBI), and extraction of tooth 65 were performed.

In the dental examination, the following were observed:

a) in tooth 55, micro cavity of caries in active enamel;

b) in tooth 54 , vestibular face fracture; c) in tooth 52, non-cavitated lesion in the vestibular and cavitated lesion in active dentin on the mesial surface;

d) in tooth 64, occlusal restoration;

e) in tooth 65, coronary destruction;

f) in tooth 36 for (occlusal) and in tooth 84 (for distal), cavitated lesion in dentin;

g) in tooth 75 , altered occlusal restoration;

h) in tooth 85, occlusal shading; and,

i) in teeth 26 and 46 , the presence of occlusal restoration.

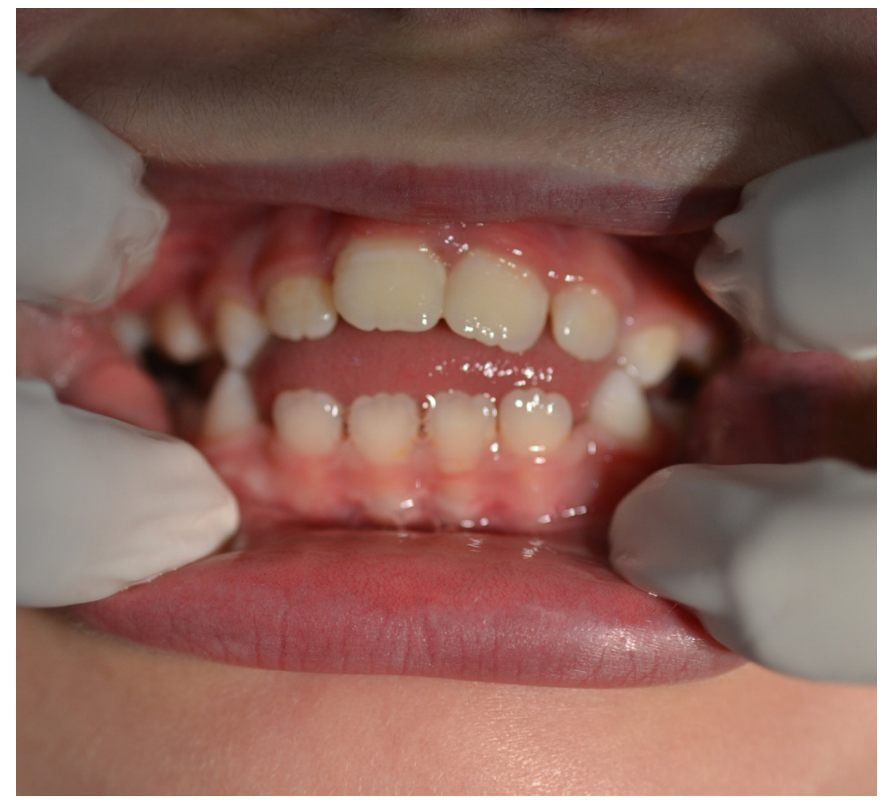

Figure 1. Intraoral aspect showing anterior open bite.

Considering the neuromotor difficulties, the patient had reasonable oral hygiene conditions, despite having a gingival bleeding test (GBI) of $12.5 \%$ and visible plaque (VPI) of $81.25 \%$. The proposed treatment was the accomplishment of oral adaptation, through the extraction of tooth 65 , supragingival plaque, and restorations of the 36,84 , and 75 teeth. Hygiene instructions were provided to prevent future dental problems. A panoramic radiography was requested to follow the dental development, and a hand and wrist radiography was requested to verify the presence of brachydactyly.

At the second appointment, the patient did not allow any procedure to be performed. Thus, the mother (the only caregiver present at the appointment) was instructed about the practice of oral hygiene and motivated to perform it because the patient has psychomotor deficiency and is in a mixed dentition period. Moreover, the patient already has caries disease in the permanent dentition. She 
was asked to brush the patient's teeth (to evaluate whether the execution was correct). Later, she was shown the most appropriate method for better oral adjustment.

In the panoramic radiography, the presence of all successive permanent teeth was verified. The chronology of the eruption was normal. Teeth 13 and 23 have an abnormal eruption axis, with tooth 23 near the root of tooth 22. Tooth 33 is malformed, and teeth 33 and 34 are rotated. The presence of brachydactyly (shortening of the fingers and toes), dystrophic dysplasia (bone dysplasia, various deformities, and malformation), and deformities in the extremities, carpi, radius, and ulna were observed in the hand and wrist radiography examination. All the bones of the hand (carpal, metacarpal, phalanges, and long bones) presented malformation due to bone dysplasia.

Another important aspect reported in the conversation with the mother and the grandmother, who is responsible for both the patient and her mother, was that the patient was using a fluoride-free toothpaste. Immediately, they were informed that the indicated toothpaste is one with fluoride and instructed so that the correct amount of dentifrice should be used.

The patient was under the care of an endocrinologist (thyroid control and other metabolic disorders, such as hypocalcaemia), pulmonologist (asthma treatment), neurologist (neuropsychomotor disability investigation), paediatrician (general monitoring), nutritionist (control of feeding since the patient is obese), and surgeon (evaluation of possible surgery, since she had a gallbladder stone of 0.6 $\mathrm{cm}$; it is not known whether it is related to the syndrome).

In relation to $\mathrm{AHO}$, when examining the oral cavity, no characteristic dental alteration was noticed in addition to malocclusion, cited by other authors3,10-13 (Figure 2). However, there is a strong tendency for the open bite to be related to psychological factors since the patient still uses a pacifier to sleep. Therefore, the grandmother and the mother were warned of the need to suspend the pacifier.

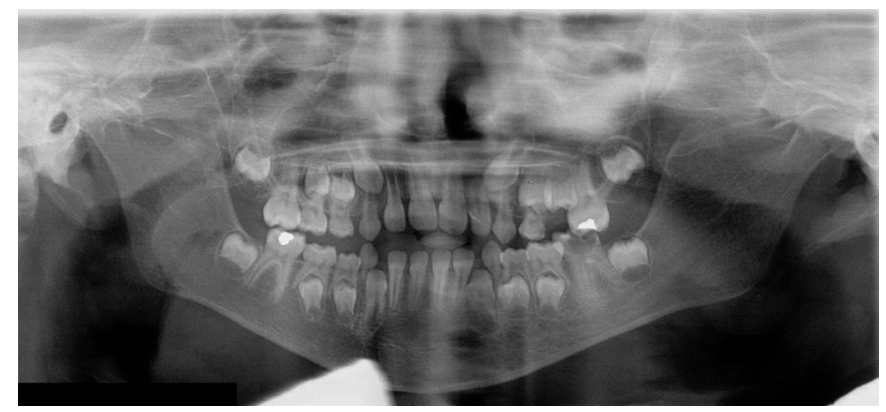

Figure 2. Radiographic image, apparently with normal eruption of teeth.

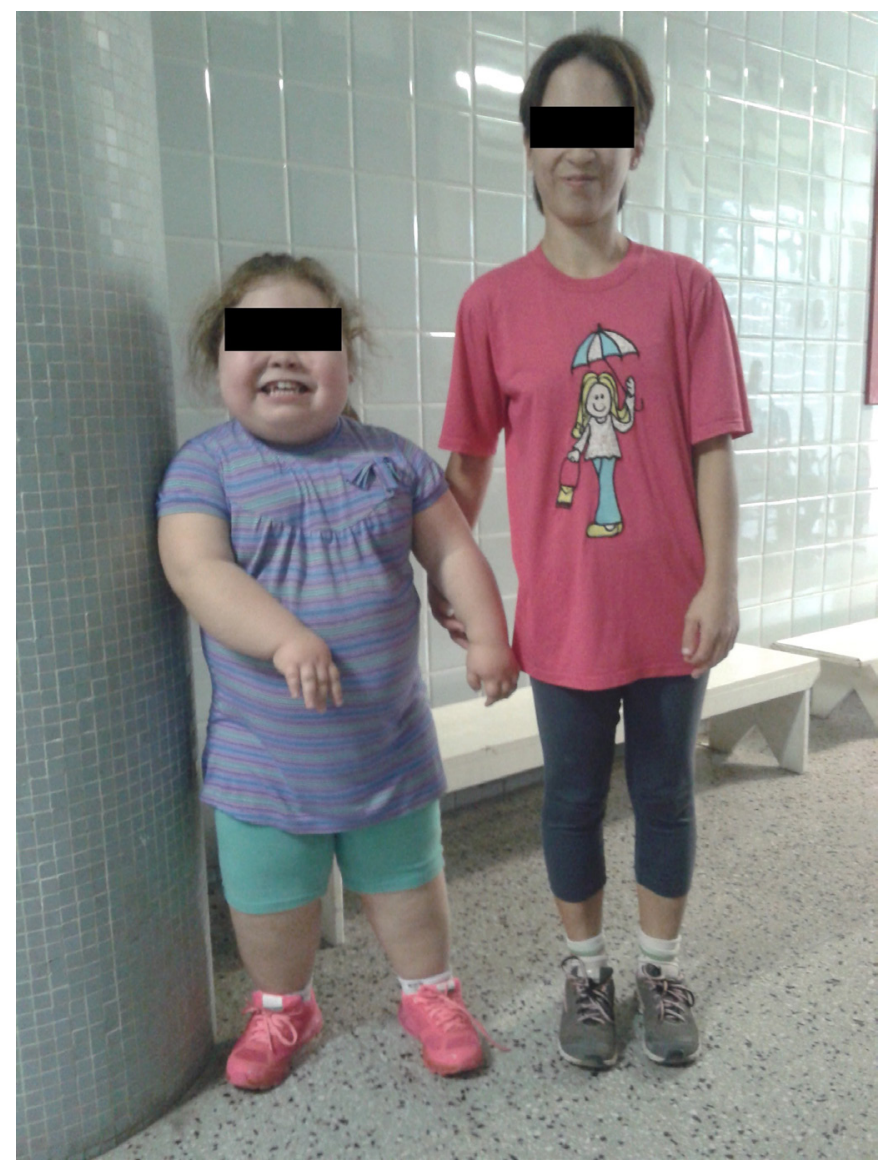

Figure 3. Characteristic physical appearance of $\mathrm{AHO}$ patient. In the photograph: mother and daughter.

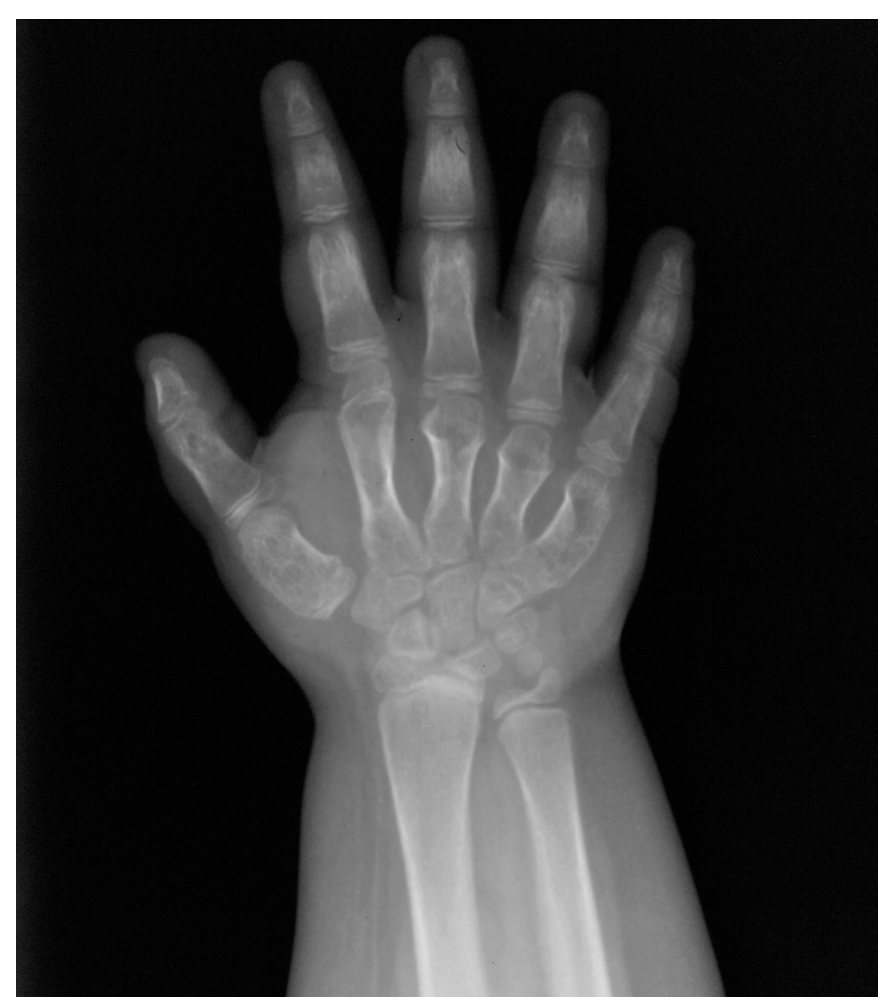

Figure 4. Hand and wrist radiograph with diagnosis of brachydactyly and bone dysplasia. 
The patient's collaboration during the care was very deficient, showing agitation and intolerance. For the continuity of her treatment aiming at the maintenance of her oral health, a referral was made to the assistance department of the UFGRS School of Dentistry for the care of patients with special needs.

\section{DISCUSSION}

The case described herein concerns AHO syndrome, which, although a rare disease that involves different clinical characteristics throughout the body, is easily identified. In this study, the patient presented some classic signs of this syndrome, such as round face, short neck, hypothyroidism, mental disability, and obesity, presenting the possible diagnosis of $\mathrm{PHP}^{1-}$ 13. The patient was female, as in most reported cases of $\mathrm{AHO}$, as the probability of occurrence is twice as

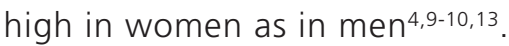

In this clinical case, the patient demonstrated mental disability and an anterior open bite; however, occlusal alteration is possibly not related to $\mathrm{AHO}$, unlike that found in other studies in relation to malocclusion ${ }^{10-12}$. The motivation for the practice of oral hygiene is extremely important since it is common for AHO patients to present bacterial plaque accumulation, caused by poor brushing due to psychomotor problems or by crowding. Thus, the patient and her caregivers were oriented in this direction, which was the same

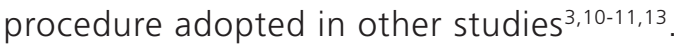

Patients with mental disabilities are considered patients with special needs (PSN) and will receive a differentiated attention in dental care. A PSN is any patient who has one or more temporary or permanent limitations of a mental, physical, sensory, emotional, growth, or medical nature that prevents him or her from being subjected to a conventional dental situation ${ }^{14}$. For the care of these patients, it is necessary that a correct approach is performed, and this will be individualised and will depend on the type of illness that the individual presents.

It is important to know the patient, his or her level of disability, and how collaborative he or she can be. From then on, planning can be done to determine which type of treatment will be most appropriate, whether performed in the office or in the surgical suite (under sedation or general anaesthesia), and whether there is a need for containment.
In addition, the involvement of the family throughout the process is very important for the improvement of the patient's health. In this clinical case, there was a certain difficulty of communication with the patient. Therefore, the family involvement was of great value ${ }^{15}$. As the patient has asthma, she was asked by the team who will attend her for an evaluation from the pulmonologist for the use of general anaesthesia in the case of hospital assistance. The recognition of PSNs and the individualisation of their treatments and a broad knowledge of the professional involved and their training in these cases are essential for the success of dental care.

Hypoplasia, ${ }^{10,12-13}$ late eruption of teeth ${ }^{12-13}$, ATM ankylosis 3,10 , xerostomia ${ }^{10-11}$, several decayed teeth $^{3,10,12}$, and dental crowding ${ }^{11,13}$, among other characteristics, were described in the literature; however, these conditions were not present in this case at the time of the examinations. There are not always dental changes in AHO patients; however, it is up to the dentist to have knowledge about this syndrome to facilitate treatment since the patient may present difficulties in collaborating with care or motor incapacity for oral health care. In addition, this knowledge is relevant for the possible identification of the syndrome and possible referral of the patient to a genetic investigation and treatment with an endocrinologist.

The need for multidisciplinary treatment is very important and is increasingly growing in dentistry. The dental surgeon should evaluate the general health condition of the patient and not only the oral health to then determine a diagnosis. However, this is only possible with the involvement of several health professionals in partnership with the dental surgeon in the diagnosis and treatment of the patient and the commitment of the professional and their interest in expanding their knowledge about different conditions. This will lead to better results and greater efficiency in the execution of dental treatment.

Monitoring the development of the patient's dentition is necessary for the prevention of oral diseases, such as caries, gingivitis, or periodontitis. In view of the neuropsychomotor disability of the patient, periodic visits to the dentist are important for follow up and evaluation of the oral cavity so that there is a reinforcement of oral hygiene guidelines for the patient and their caregivers. The frequency of these 
visits will occur according to the collaboration and oral conditions of the patient (every month, every three months, every six months, or every year).

\section{CONCLUSION}

The diagnosis of patients with this syndrome is challenging and requires multidisciplinary care. In the present case, it was only possible to extract tooth

\section{REFERENCES}

1. Maeda SS, Fortes EM, Oliveira UM, Borba VCZ, Castro ML. Hipoparatiroidismo e pseudohipoparatiroidismo. Arq Bras Endocrinol Metab. 2006;50(4):664-73. doi: 10.1590/S000427302006000400012

2. De Nanclares GP, Fernández-Rebollo E, Gaztambide S, Castaño L. Genética del seudohipoparatiroidismo: bases para el consejo genético. Endocrinol Nutr. 2008;55(10):476-83. doi: 10.1016/ S1575-0922(08)75844-3

3. DuVal MG, Davidson S, Ho A, Cohen R, Park M, Nourian S, et al. Albright's Hereditary Osteodystrophy with Extensive Heterotopic Ossification of the Oral and Maxillofacial Region: How Fetuin Research May Help a Seemingly Impossible Condition. J Can Dent Assoc. 2007;73(9):845-50.

4. National Organization for Rare Disorders (NORD) [cited 2017 Mar 10]. Available from: <https://rarediseases.org/rare-diseases/ pseudohypoparathyroidism/>.

5. Ahrens $W$, Hiort $O$. Determination of Gsa protein activity in albright's hereditary osteodystrophy. J Pediatr Endocrinol Metab. 2006;19(2):647-651.

6. Burgert T, Markowitz M. Understanding and recognizing pseudohypoparathyroidism. Pediatr Rev. 2005;26(8):308-309. doi: 10.1542/pir.26-8-308

7. Thompson \& Thompson. Genética médica. In: Nussbaum, Mc Innes, Willard. Padrões de herança de genes únicos. $7^{a}$ ed. Rio de Janeiro: Elsevier; 2008, p. 141-3.

8. Arias MP. Tratado de endocrinología pediátrica. $2^{a}$ edição. In: Hipoparatireoidismo. Madrid: Díaz de Santos; 1997. p. 649-51.
65 and provide oral hygiene instructions. The dental treatment of patients with this syndrome requires specialised care.

\section{Collaborators}

All the authors participated in attending the patient; reading the literature related to the case reading and writing the article.

9. Jones KL. Padrões reconhecíveis de malformações congênitas. $5^{\text {a }}$ ed. São Paulo: Ed. Manole; 1998.

10. Hugar D, Sangameshwar S, Santosh H, Megha K. Albright hereditary osteodystrophy: a case report. J Clin Diagn Res. 2014;8(10):28-30. doi: 10.7860/JCDR/2014/10913.5041

11. Gomes MF, Camargo AMA, Sampaio TA, Graziozi MAOC, Armond MC. Oral manifestations of Albright hereditary osteodystrophy: a case report. Rev Hosp Clín Fac Med São Paulo. 2002;57(4):161-6. doi: 10.1590/S0041-87812002000400006

12. Goswami M, Verma M, Singh A, Grewal H, Kumar G. Albright hereditary osteodystrophy: A rare case report. J Indian Soc Pedod Prev Dent. 2009;27(3):184-8. doi: 10.4103/0970-4388.57101

13. Loredo AA, Gamboa ACO, Fernández JMT, Díaz MAS. Osteodistrofia hereditaria de Albright (Pseudohipoparatiroidismo, pseudopseudohipoparatiroidismo). Reporte de un caso. Rev ADM. 1999;44(4):163-5.

14. Brasil. Ministério da Saúde. Cadernos de Atenção Básica, n. 17. Saúde Bucal. Brasília: Ministério da Saúde; 2006. 67 p. [citado 2017 Mar 10]. Disponível em: <http://189.28.128.100/dab/ docs/publicacoes/cadernos_ab/abcad17.pdf>.

15. Silva LCP. Odontologia para pacientes com necessidades especiais: protocolos para o atendimento clínico. São Paulo: Santos; 2009. 